\title{
Craddock Massif and Vinson Massif remeasured
}

\author{
Damien Gildea ${ }^{1}$ and John Splettstoesser ${ }^{2}$ \\ 'The Omega Foundation, Incline Village, Nevada U.S.A. 89450 (dageogil@tpqi.com.au) \\ 2P.O. Box 515, Waconia, Minnesota U.S.A. 55387 (spletts@usfamily.net)
}

\begin{abstract}
The highest peak in Antarctica, the Vinson Massif $\left(78^{\circ} 35^{\prime} \mathrm{S}, 85^{\circ} 25^{\prime} \mathrm{W}\right)$, is at an elevation of $4892 \mathrm{~m}(16,046$ $\mathrm{ft}$ ), as determined in 2004. Measurements of the elevation have fluctuated over the years, from its earliest surveyed elevation of $5140 \mathrm{~m}(16,859 \mathrm{ft})$, to its present height. Vinson Massif and three of its near neighbors in the Sentinel Range of the Ellsworth Mountains are the highest peaks in Antarctica, making them a favorite objective of mountaineers. Well over 1,100 people have climbed Vinson since the first ascent by a team in the 1966-67 austral summer. The range is composed of Crashsite quartzite, making the Sentinel's very resistant to erosion. Very accurate elevations have been achieved annually by GPS mapping done by a climbing team sponsored by the Omega Foundation, active in Antarctica since 1998. The Craddock Massif now includes Mt. Craddock, the ninth highest peak in Antarctica, at $4368 \mathrm{~m}(14,327 \mathrm{ft})$. Both are named for Campbell Craddock*, a U.S. geologist active in Antarctic research beginning in 1959-60.

*Deceased, 23 July 2006.
\end{abstract}

Citation: Gildea, D., and J. Splettstoesser (2007), Craddock Massif and Vinson Massif remeasured, in Antarctica: A Keystone in a Changing World Online Proceedings of the $10^{\text {th }}$ ISAES, edited by A.K. Cooper and C.R. Raymond et al., USGS Open-File Report 2007-1047, Short Research Paper 069, 3 p.; doi:10.3133/of2007-1047.srp069

\section{Introduction}

The Ellsworth Mountains lie in the interior of West Antarctica, centered at about $79^{\circ} \mathrm{S}, 85^{\circ} \mathrm{W}$. The mountains occur in two major segments, the Sentinel Range to the north, and the Heritage Range to the south, separated by the Minnesota Glacier. The landscape is dominated by rugged, angular peaks including the Vinson Massif, the highest mountain in Antarctica (Webers et al., 1992, p. xi). The mountains are of special interest geologically for reasons described by authors elsewhere in this volume, and in the reference by Webers et al. (1992). This paper discusses the discovery and early exploration of the mountains, and recent efforts by climbing teams to measure accurately the highest peaks in Antarctica, 8 out of 10 of them in the Sentinel Range.

\section{History of discovery and selected expeditions}

The Ellsworth Mountains were discovered by the American aviator Lincoln Ellsworth on November 23, 1935, during his flight across Antarctica from Dundee Island near the tip of the Antarctic Peninsula to a point just short of Admiral Byrd's Little America base on the Ross Ice Shelf (Ellsworth, 1936, 1937). Ellsworth saw only the northern part of the Sentinel Range, and named several features - Mount Lymburner (second pilot on the expedition); Polarstar Peak (for his airplane, Polar Star); Mt. Ulmer (for his wife, Mary Louise Ulmer); Mt. Wyatt Earp (for his expedition ship, Wyatt Earp); and the Sentinel Range. It would seem that he never saw the highest peaks to the south, including Vinson Massif, named for U.S. Representative Carl G. Vinson of Georgia. The mountains were next seen on January 12, 1958, during an IGY oversnow traverse led by Charles R. Bentley (Univ. of Wisconsin). Two outlying nunataks were visited and samples of the rocks were taken. Positions of major peaks were established by ground surveying. (Further details on the history discussed here can be found in Webers et al., 1992, p. xi-xiii.)
The U.S. Navy Squadron VX-6 photographed the Sentinel Range in trimetrogon aerial photographic coverage on December 14, 1959, and along with subsequent ground surveys, resulted in a series of 1:250,000-scale topographic maps that were published by the U.S. Geological Survey (1962 - Newcomer Glacier, Nimitz Glacier, Vinson Massif sheets). On December 26, 1959, Campbell Craddock was part of a group that visited the Ellsworth Mountains on the ground, stopping at Pipe Peak, Heritage Range, and rock samples were collected. On November 4, 1962, the U.S. Navy photographed the Heritage Range, and topographic maps were later published of the Liberty Hills and Union Glacier sheets (U.S. Geological Survey, 1967 -Liberty Hills, Union Glacier).

The first of three successive geologic studies of the Ellsworth Mountains under the direction of Campbell Craddock was conducted in the 1961-62 austral summer, when a 4-man team from the University of Minnesota traversed most of the western Sentinel Range and some of the eastern Heritage Range by motor toboggans (Anderson et al., 1962). Motor toboggans were again used in the 1962-63 season, and in 1963-64 the expedition had the support of U.S. Army UH-1B helicopters staged at a base camp on the Minnesota Glacier. Geologic field studies continued from other U.S. institutions in 1966-67, and by a Norwegian team in 1974-75. The durable rock type quartzite and glacial erosion have produced the topography, where in the Sentinel Range, numerous examples of arêtes, horns, cirques, and tors occur. Rocks of the Crashsite Group (formerly Crashsite Quartzite), a 2,600- to 3400-m-thick (8528- to 11,152-ft-thick) unit of Cambrian to Devonian age, occur in most of the Sentinel Range as part of a north-plunging, Gondwanide thrust belt (Craddock et al., 1986).

A U.S. mountaineering expedition made the first ascents of the highest peaks in the 1966-67 austral 
summer, including the Vinson Massif. The first of annual climbs of Vinson Massif occurred in November 1983, and many times since (see below).

The largest geologic field program in the Ellsworth Mountains was conducted in the 1979-80 season, when U.S. Navy UH-1N helicopters operated from a base camp in the northwestern Heritage Range (Splettstoesser et al., 1982). The program was under the direction of Prof. Gerald F. Webers, of Macalester College, St. Paul, Minnesota, with Campbell Craddock a participant.

\section{Table 1 "Seven Summits", highest mountains on seven continents}

$\begin{array}{llcc}\text { Asia } & \text { Mt. Everest } & 29,021 \mathrm{ft} & 8848 \mathrm{~m} \\ \text { South America } & \text { Cerro Aconcagua } & 22,929 & 6960 \\ \text { North America } & \text { Mt. McKinley (Denali) } & 20,313 & 6193 \\ \text { Africa } & \text { Mt. Kilimanjaro } & 19,332 & 5894 \\ \text { Europe } & \text { Mt. Elbrus } & 18,476 & 5633 \\ \text { Antarctica } & \text { Vinson Massif } & 16,046 & 4892 \\ \text { Australia } & \text { Mt. Kosciusko } & 7,314 & 2230\end{array}$

If Australasia is considered as the "continent":

$\begin{array}{llrr}\text { Irian Jaya, Indonesia } & \text { Carstenz Pyramid } & \text { c. } 15,744 & \text { c. } 4800 \\ \text { New Zealand } & \text { Mt. Cook } & 12,349 & 3765\end{array}$

Note: Elevations from Gildea (1998) and The Omega Foundation for Vinson Massif.

\section{Mountaineering and surveying}

Mountaineering became a popular activity in the Ellsworth Mountains with the opening of a temporary summer camp established at Patriot Hills in the southern Heritage Range in the 1980s. (Swithinbank, 1988). Part of the interest of mountaineers is that of the Vinson Massif, the highest peak on the continent. Mountaineers achieving a "Seven-Summits" status choose Vinson because it is the highest on one of the seven continents (Table 1). Another level of difficulty for climbers is that of the fourteen peaks higher than 8000 meters, perhaps one of the most arduous to achieve.

The advent of a mountaineering team in Antarctica in 1998, sponsored by The Omega Foundation and led by Damien Gildea, Vinson Massif and adjacent peaks were surveyed in austral summers with extreme accuracy using a Trimble 5700 GPS receiver. Data are then relayed to Australia for processing. This program has continued annually through the 2006-07 austral summer. The instruments are placed on the summit of each peak and left for a period of time that is deemed sufficient to collect as much satellite information as possible in order to achieve an accurate elevation. As a result, Vinson Massif has been ascribed an elevation within a tenth of a foot. The Vinson Massif and other high peaks in the Sentinel Range have been visited repeatedly, with some still to be climbed and measured for elevations (planned for 2006-07 and succeeding summers). The figures for each are listed in Table 2, which also includes two peaks in the Transantarctic Mountains. The 10 peaks in Table 2 are the highest in Antarctica. Mt. Vinson is newly named as the Vinson Massif. The Craddock Massif (new name) includes Mt. Craddock, Mt. Rutford (for R.H. Rutford, Antarctic geologist and colleague of Craddock), Rada Peak, and Bugueño Pinnacle, the latter two features for climbing associates of Damien Gildea, Camilo Rada

Table 2 Eight of the highest peaks in the Sentinel Range, Ellsworth Mountains, and two for comparison (Mts. Kirkpatrick and Elizabeth) in the Transantarctic Mountains

$\begin{array}{lll}\text { 1. Mt. Vinson } & 16,046 \mathrm{ft} & 4892 \mathrm{~m} \\ \text { 2. Mt. Tyree } & 15,915 & 4852^{*} \\ \text { 3. Mt. Shinn } & 15,288 & 4660 \\ \text { 4. Mt. Gardner } & 15,045 & 4573 \\ \text { 5. Mt. Kirkpatrick } & 14,852 & 4528^{*} \\ \text { 6. Mt. Elizabeth } & 14,694 & 4480^{*} \\ \text { 7. Mt. Rutford } & 14,685 & 4477 \\ \text { 8. Rada Peak } & 14,439 & 4402 \\ \text { 9. Mt. Craddock } & 14,327 & 4368 \\ \text { 10. Mt. Epperley } & 14,298 & 4359^{*}\end{array}$

*No GPS measurements by Omega Project. Elevations of all others have been accurately surveyed by GPS by Omega. 
and Manuel Bugueño). The first ascent of Mt. Craddock was made in January 1992. Mt. Vinson is one of several names recently approved by the U.S. Advisory Committee on Antarctic Names.

The Antarctic Mountaineering Chronology (Gildea, 1998) includes a record of ascents in Antarctica and South Georgia through February 1998 -- each entry includes the name of the mountain/peak, its location, date of ascent, and names of climbers. A topographic map at a scale of 1:50,000 produced in 2006 illustrates the major features of this part of the Sentinel Range, a product of accurate measurements by The Omega Foundation (2006) team to date. Progress on this GPS mapping project can be found on the following website http://www.theomegafoundation.org.

\section{Logistics for mountaineering in the Sentinel Range}

The most notable feature of recent Antarctic mountaineering has been the relatively large number of climbers making ascents of Vinson Massif. Gildea (1998, p. 9) lists more than 400 climbers of Vinson as of Feb. 1998, and through the 2006-07 austral summer it is estimated that the number has reached some 1,100 or more. This has been made possible through the efforts of a private company, Adventure Network International (ANI), formed in the mid-1980s to provide a base camp for climbers and other adventurers visiting the interior. The company has now been joined by Antarctic Logistics and Expeditions (ALE) to provide similar services for climbers and others. The temporary base camp is located at Patriot Hills in the southern Heritage Range, at about $80^{\circ} 18^{\prime} \mathrm{S}, 81^{\circ} 22^{\prime} \mathrm{W}$, where a large blue-ice area exists that is suitable for landing wheeled aircraft (Swithinbank, 1988). Mass balance measurements of the blue-ice area indicate that the ice is in equilibrium Casassa et al., 1998), thus providing a stable runway without need for grooming.

Visitors arrive by aircraft from Punta Arenas, Chile, followed by appropriate conditioning and preparation at Patriot Hills base camp. A later flight by smaller aircraft transports climbers to a base camp adjacent to Vinson Massif, some 125 miles $(200 \mathrm{~km})$ north of Patriot Hills camp. All flights are weather-dependent. From there a number of potential routes to the summits of Vinson and nearby peaks exist, as shown on the Omega Foundation map (2006). As with other visitors to Antarctica, those involved in programs sponsored by Antarctic Treaty signatories or tourists who set foot on the continent, all activities conducted at Patriot Hills camp or in the
Sentinel Range include removal of all wastes at the conclusion of the event.

\section{Summary}

The combination of the temporary summer camp at Patriot Hills, the convenient air service from Punta Arenas, Chile, to Antarctica, and a large clientele of aspiring mountaineers to climb the highest peaks in Antarctica will continue in the foreseeable future. The detailed map produced by Damien Gildea and Camilo Rada for The Omega Foundation provides accurate mapping and elevations of major peaks in the Sentinel Range as a guide for later expeditions, as well as a significant contribution to the mapping of Antarctica.

Acknowledgements. The Omega Foundation acknowledges coordination with the USGS Polar Programs Office, the US Antarctic Resource Center, Reston, Virginia, and the US Advisory Committee on Antarctic Names (ACAN). The Omega Foundation is a non-profit 501(c)(3) Private Operating Foundation dedicated to supporting scientific, environmental, educational and literary projects in the Antarctic region. www.theomegafoundation.org. The manuscript benefited from a review by J. Craddock and advice from W. LeMasurier, organizer of a special session in memory of C. Craddock.

\section{References}

Anderson, J.J., Bastien, T.B., Schmidt, P.G., Splettstoesser, J.F., and C. Craddock (1962), Antarctica: Geology of the Ellsworth Mountains, Science, 138, 824-825.

Casassa, G., Brecher, H.H., Cardenas, C., and A. Rivera (1998), Mass balance of the Antarctic ice sheet at Patriot Hills, Annals of Glaciology, 27, 130-134.

Craddock, C., Webers, G.F., Rutford, R.H., Spörli, K.B., and J.J. Anderson (1986), Geologic map of the Ellsworth Mountains, Antarctica, Geological Society of America, Map and Chart Series MC-57, scale 1:250,000.

Gildea, D. (1998), The Antarctic Mountaineering Chronology, Fyshwick, ACT, Australia, Paragon Printers, 110 pp.

Ellsworth, L. (1936), My flight across Antarctica, National Geographic Magazine, 70, 1-35.

Ellsworth, L. (1937), Beyond Horizons, N.Y., Doubleday, Doran, Garden City, 403 pp.

The Omega Foundation (2006), Vinson Massif \& The Sentinel Range, Ellsworth Mountains, Antarctica, 1:50,000 Topographical Map, Nevada, Incline Village.

Splettstoesser, J.F., Webers, G.F., and D.B. Waldrip, (1982), Logistic aspects of geological studies in the Ellsworth Mountains, Antarctica, 1979-80, Polar Record, 21, 147-159.

U.S. Geological Survey, 1:250,000 Reconnaissance Series Maps: Liberty Hills, 1967; Newcomer Glacier, 1962; Nimitz Glacier, 1962; Union Glacier, 1967; Vinson Massif, 1962.

Swithinbank, C. (1988), Antarctic Airways: Antarctica's first commercial airline, Polar Record, 24, 313-316.

Webers, G.F., Craddock, C., and J.F. Splettstoesser, eds. (1992), Geology and paleontology of the Ellsworth Mountains, West Antarctica: Boulder, Colorado, Geological Society of America Memoir 170, 459 pp. 